\author{
A.Zh. Satybaldin, A.K. Muratova, I.A. Kyrgyzalina, \\ Z.K. Aitpaeva, B.R. Nussupbekov, M.I. Baikenov \\ Ye.A. Buketov Karaganda State University, Kazakhstan \\ (E-mail: zamik1981@mail.ru)
}

\title{
Method of definition thermodynamic functions of heavy oil organic mass processed by underwater spark discharge
}

\begin{abstract}
The methods of preparing oils for pipeline transport associated with the mechanical effect on high-viscosity and highly paraffinic oil is today a topical problem for refineries. As is known, the most promising method today is the method of electrohydropulse discharges, which allows to regulate the oil dispersed system properties by changing the sizes and forms of complex structural units. Creation environmentally friendly synthetic liquid fuels production supposes the improvement technology of upgrading high-viscosity oil process. To solve this problem, along with experimental studies, thermodynamic analysis of various upgrading ways of high-viscosity oil is necessary. Such calculations must be carried out by giving different compounds' classes contained in highly viscous hydrocarbon compounds. A deep study of the transformations mechanism of high-viscosity oil's organic mass from the Karazhanbas field is a prerequisite for developing new highly effective hydrogenation processes. Therefore, this article is devoted to study kinetics and thermodynamics of the high-viscosity oil processing from the Karazhanbas field.
\end{abstract}

Keywords: electrohydraulic effect, oil clarification, dielectric permeability, temperature, frequence, hydrogen sulfide, polarizability, thermodynamic coefficient, oil products, heterogeneous environment.

The analysis of references shows that there are no quantitative interrelations between alkanes and aromatic hydrocarbons and their thermodynamic parameters' structure which define intermolecular interaction extent that is phase transition warmth. Researches of heavy hydrocarbonic raw materials transformation's thermodynamic into low-molecular connections are generally presented by determination aromatic structures which [1] model structure in ratios of organic mass fragments of coal, heavy oil and oil residues.

For definition thermodynamic functions of heavy oil's organic mass we used the additive method developed by professor A.M. Gyulmaliyev [2]. The choice of parameters depending on hybrid conditions of carbon atoms and hydrogen atoms related by a chemical bond is defined for calculation temperature dependence of thermodynamic functions of an arbitrary structured heavy oil's organic part. Hydrocarbons' arbitrary structure having various parametrs set of carbon atoms and various hydrogen atoms' hybrid conditions which are connected by a chemical bond is offered.

Heteroatoms are considered at the same time as a part of functional groups. According to an additive method [2] the thermodynamic Fm function of a molecule $M$ it is possible to present the sums in the form:

$$
\Phi_{M}=\sum_{\mu} f_{\mu}
$$

where $f_{\mu}$ - the property $\Phi$ size having on $\mu$ th type of structural group.

List of atomic groups used to calculate the thermodynamic functions of hydrocarbons and other organic molecules is given in work [2]. For each atom group, the values of the quantities $C_{p}(T) \Delta H_{298}$ and $\Delta S_{298}$ were determined from the corresponding data for model molecules.

The calculation scheme for determining the parameters is as follows. The thermodynamic function of a molecule $M$ at a given temperature $\Phi_{M}(T)$ is represented as a corresponding values' sum of the structure group $f_{i}(T)$

$$
\Phi_{M}(T)=\sum \chi_{i} f_{i}(T)
$$

The values of entropy $\Delta S$, enthalpy $\Delta H$ and Gibbs energy for atomic groups at temperatures 298 $1000 \mathrm{~K}$ of highly viscous oil (HVO) are given in Tables $1-3$, before the post-treatment by electrohydropulse action with the help of an apparatus that allows obtaining an underwater spark discharge (USD) [3]. 
Thermodynamic function (enthalpy) of heavy oil's organic mass from the Karazhanbas field (initial oil and hydrogenates obtained after treatment with HVO by electrohydraulic effect (EHE)

\begin{tabular}{|c|c|c|c|c|c|c|}
\hline \multirow{2}{*}{$T, \mathrm{~K}$} & \multicolumn{7}{|c|}{$\Delta H, \mathrm{~J} / \mathrm{mole} \mathrm{K}^{\mathrm{K}}$} \\
\cline { 2 - 7 } & Source oil & Test 1 & Test 2 & Test 3 & Test 4 & Test 5 \\
\hline 298 & -7850179 & -11533826 & -7853022 & -6831828 & -7219747 & 14361641 \\
\hline 300 & -7839360 & -11523200 & -7841876 & -6820142 & -7208384 & -14348988 \\
\hline 400 & -7221749 & -10919066 & -7205282 & -6150686 & -6558945 & -13630106 \\
\hline 500 & -6464595 & -10182729 & -6424703 & -5326514 & -5761929 & -12755597 \\
\hline 600 & -5583990 & -9329899 & -5517018 & -4366091 & -4834745 & -11745075 \\
\hline 700 & -4596039 & -8376275 & -4499106 & -3287877 & -3794823 & -10618169 \\
\hline 800 & -3516828 & -7337560 & -3387846 & -2110331 & -2659577 & -9394505 \\
\hline 900 & -2362465 & -6229460 & -2200113 & -851913 & -1446422 & -8093704 \\
\hline 1000 & -1149038 & -5067682 & -952786 & 468913,2 & -172781 & -6735393 \\
\hline
\end{tabular}

Note. Test 1 - fraction with boiling point up to $3000 \mathrm{C}$, amount of added hydrogen donor $0.1 \mathrm{ml}$ to $\mathrm{HVO}$, interelectrode distance $L=4 \mathrm{~mm}$;

- test 14 - fraction with boiling point up to $3000 \mathrm{C}$, amount of added hydrogen donor $0.2 \mathrm{ml}$ to HVO and interelectrode distance $L=8 \mathrm{~mm}$;

- test 10 - fraction with a boiling point up to $3000 \mathrm{C}$, quantity of donor added to the hydrogen of $0.4 \mathrm{ml}$ to $\mathrm{HVO}$ and interelectrode distance $L=6 \mathrm{~mm}$;

- test 12 - fraction with a boiling point up to $3000 \mathrm{C}$, the amount of added hydrogen donor $0.5 \mathrm{ml}$ to $\mathrm{HVO}$ and the interelectrode distance $L=12 \mathrm{~mm}$;

- test 24 - fraction with boiling point up to $3000 \mathrm{C}$, amount of added hydrogen donor $0.2 \mathrm{ml}$ to HVO and interelectrode distance $L=12 \mathrm{~mm}$.

Thermodynamic function (entropy) of heavy oil's organic mass from the Karazhanbas field (initial oil and hydrogenates obtained after HVO treatment with the help of EHE)

\begin{tabular}{|c|c|c|c|c|c|c|}
\hline$T, K$ & \multicolumn{7}{|c|}{$\Delta S, \mathrm{~J} / \mathrm{mole}$ K K } & Test 5 \\
\hline & Source oil & Test 1 & Test 2 & Test 3 & 13 & 19131,71 \\
\hline 298 & 13945,28 & 16615,45 & 13354,84 & 13582,55 & 13081,09 & 19211936 \\
\hline 300 & 13988,19 & 16657,8 & 13398,83 & 13628,38 & 13125,71 & 21595041 \\
\hline 400 & 16078,3 & 18712,68 & 15542,13 & 15867,65 & 15302,82 & 23844492 \\
\hline 500 & 18063,41 & 20652,83 & 17577,79 & 18002,24 & 17374,99 & 25967233 \\
\hline 600 & 19946,49 & 22485,7 & 19508,41 & 20030,72 & 19342,56 & 27966970 \\
\hline 700 & 21729,12 & 24215,24 & 21335,37 & 21952,36 & 21205,7 & 29845922 \\
\hline 800 & 23412,24 & 25843,83 & 23059,49 & 23766,7 & 22964,51 & 31605508 \\
\hline 900 & 24996,48 & 27372,99 & 24681,31 & 25473,45 & 24619,06 & 33246709 \\
\hline 1000 & 26482,24 & 28803,77 & 26201,18 & 27072,41 & 26169,4 & \\
\hline
\end{tabular}

Note. Test 1 - fraction with boiling point up to $3000 \mathrm{C}$, amount of added hydrogen donor $0.1 \mathrm{ml}$ to HVO, interelectrode distance $L=4 \mathrm{~mm}$;

- test 14 - fraction with boiling point up to $3000 \mathrm{C}$, amount of added hydrogen donor $0.2 \mathrm{ml}$ to HVO and interelectrode distance $L=8 \mathrm{~mm}$;

- test 10 - fraction with boiling point up to $3000 \mathrm{C}$, amount of added hydrogen donor $0.4 \mathrm{ml}$ to HVO and interelectrode distance $L=6 \mathrm{~mm}$;

- test 12 - fraction with a boiling point up to $3000 \mathrm{C}$, the amount of added hydrogen donor $0.5 \mathrm{ml}$ to $\mathrm{HVO}$ and the interelectrode distance $L=12 \mathrm{~mm}$;

- test 24 - fraction with boiling point up to $3000 \mathrm{C}$, amount of added hydrogen donor $0.2 \mathrm{ml}$ to HVO and interelectrode distance $L=12 \mathrm{~mm}$. 
Thermodynamic function (Gibbs energy) of heavy oil's organic mass from the Karazhanbas field (initial oil and hydrogenates obtained after treatment with HVO by EHE)

\begin{tabular}{|c|c|c|c|c|c|c|}
\hline \multirow{2}{*}{$T, K$} & \multicolumn{7}{|c|}{$\Delta G, \mathrm{~J} /(\mathrm{mole}$ *K) } \\
\cline { 2 - 7 } & Source oil & Test1 & Test 2 & Test 3 & Test 4 & Test 5 \\
\hline 298 & -11302292 & -15704490 & -11160991 & -113927 & -10488294 & -19358423 \\
\hline 300 & -11325528 & -15732563 & -11183265 & -136029 & -10510283 & -19392031 \\
\hline 400 & -12577624 & -17224399 & -12389934 & -1338893 & -11704815 & -21177743 \\
\hline 500 & -14000990 & -18882912 & -13773153 & -2727864 & -13080179 & -23162378 \\
\hline 600 & -15587703 & -20699736 & -1524831 & -4294937 & -14628043 & -25335390 \\
\hline 700 & -17330057 & -22667059 & -17037077 & -6032002 & -16340088 & -27686752 \\
\hline 800 & -19220468 & -24777382 & -18902104 & -7930900 & -18208025 & -30206711 \\
\hline 900 & -21251431 & -27023387 & -20912183 & -9983421 & -20223554 & -32885698 \\
\hline 1000 & -23415483 & -29397888 & -23059638 & -2181344 & -22378400 & -35714266 \\
\hline
\end{tabular}

Note. Test 1 - fraction with boiling point up to $3000 \mathrm{C}$, amount of added hydrogen donor $0.1 \mathrm{ml}$ to HVO, interelectrode distance $L=4 \mathrm{~mm}$;

- test 14 - fraction with boiling point up to $3000 \mathrm{C}$, amount of added hydrogen donor $0.2 \mathrm{ml}$ to $\mathrm{HVO}$ and interelectrode distance $L=8 \mathrm{~mm}$;

- test 10 - fraction with boiling point up to $3000 \mathrm{C}$, amount of added hydrogen donor $0.4 \mathrm{ml}$ to HVO and interelectrode distance $L=6 \mathrm{~mm}$;

- test 12 - fraction with a boiling point up to $3000 \mathrm{C}$, the amount of added hydrogen donor $0.5 \mathrm{ml}$ to $\mathrm{HVO}$ and the interelectrode distance $L=12 \mathrm{~mm}$;

- test 24 - fraction with boiling point up to $3000 \mathrm{C}$, amount of added hydrogen donor $0.2 \mathrm{ml}$ to $\mathrm{HVO}$ and interelectrode distance $L=12 \mathrm{~mm}$.

Calculation of the temperature dependence $C_{p}$ fragments were carried out by a quadratic function:

$$
C_{3}^{0}=\alpha+\beta * c T^{2},
$$

where $\alpha, \beta, c$ - coefficients.

Further, according to equation (1), for a molecule at a given temperature, $\Delta C_{p . u}(T)$ and $\Delta S_{M}(T)$ :

$$
\begin{gathered}
\Delta C_{p . M}(T)=C_{p . M}(T)-\sum_{A} C_{p . A}(T) ; \\
\Delta S_{M}(T)=S_{M}(T)-\sum_{A} S_{A}(T) .
\end{gathered}
$$

In this case, $C_{p}$ and $S_{A}$ the heat capacity and entropy of the atoms forming the molecule $M$, respectively, were calculated from the formula 3 , and the values of the coefficients $\alpha, \beta, c$ for $\Delta C_{3 A}$ and $S_{A}$ atoms $\mathrm{H}, \mathrm{C}, \mathrm{N}, \mathrm{O}, \mathrm{S}$ The following Table 4 shows the calculated data for the elemental composition of the initial and processed heavy oil samples.

The enthalpy $\Delta H_{M}$ and entropy $\Delta S_{M}$ changes in the molecule as a function of temperature were calculated using the following equations:

$$
\begin{gathered}
\Delta H(T T)=\Delta H_{298}+\int_{298}^{T} \Delta C_{p . M}(T) d T ; \\
\Delta S_{M}(T)=\Delta S_{298}=\Delta T_{298}+\int_{298}^{T} \Delta C_{p . M}(T) d(\ln T) .
\end{gathered}
$$

Taking into account 3 from equation ( 6 and 7), we have:

$$
\begin{gathered}
\Delta H(T)=\Delta H_{298}+\alpha(T-298)+\frac{\beta}{2}\left[T^{2}-298^{2}\right]+\frac{\gamma}{3}\left[T^{3}-298^{3}\right], \\
\Delta S(T) \Delta S_{298}+\alpha \ln \frac{T}{298}+\beta(T-298)+\frac{\gamma}{2}\left[T^{2}-298\right],
\end{gathered}
$$

where $\alpha=\sum_{\mu} \alpha_{\mu} ; \beta=\sum_{\mu} b_{\mu}$ and $\gamma=\sum_{\mu} c_{\mu}$. 
Calculated data of the temperature dependence of the initial and processed heat capacities test (EHE) of heavy oil

\begin{tabular}{|c|c|c|c|c|}
\hline \multirow[t]{2}{*}{ Number of test } & \multicolumn{3}{|c|}{$\begin{array}{l}\text { The coefficient of equation } \\
C_{3}^{0}=\alpha+\beta^{*} c T^{2} \mathrm{~J} /(\text { mole } * \mathrm{~K})\end{array}$} & \multirow[t]{2}{*}{$\Delta T, K$} \\
\hline & $\alpha$ & $\beta * 10$ & $\beta * 10$ & \\
\hline Source heavy oil & $2,99469 \mathrm{E}+0,1$ & $5,72565 \mathrm{E}+00 * \mathrm{~T}$ & $2,31870 \mathrm{E}-0,3 * \mathrm{~T}^{2}$ & $298-1000$ \\
\hline Test 1 & $7,49978 \mathrm{E}+0,1$ & $5,9140 \mathrm{E}+00 * \mathrm{~T}$ & $2,26054 \mathrm{E}-0,3 * \mathrm{~T}^{2}$ & $298-1000$ \\
\hline Test 4 & $2,60998 \mathrm{E}+0,1$ & $5,89966 \mathrm{E}+00 * \mathrm{~T}$ & $2,4064 \mathrm{E}-0,3 * \mathrm{~T}^{2}$ & $298-1000$ \\
\hline Test 10 & $-1,42336 \mathrm{E}+0,1$ & $6,306+6 \mathrm{E}+00 * \mathrm{~T}$ & $2,59632 \mathrm{E}-0,3 * \mathrm{~T}^{2}$ & $298-1000$ \\
\hline Test 12 & $3,33336 \mathrm{E}+0,6$ & $6,06994 \mathrm{E}+00 * \mathrm{~T}$ & $2,48894 \mathrm{E}-0,3 * \mathrm{~T}^{2}$ & $298-1000$ \\
\hline Test 24 & $6,99800 \mathrm{E}+0,1$ & $6,44988 \mathrm{E}+00 * \mathrm{~T}$ & $2,74071 \mathrm{E}-0,3 * \mathrm{~T}^{2}$ & $298-1000$ \\
\hline
\end{tabular}

Note. Test 1 - fraction with boiling point up to $3000 \mathrm{C}$, amount of added hydrogen donor $0.1 \mathrm{ml}$ to heavy oil, interelectrode distance $l p=4 \mathrm{~mm}$;

- test 4 - fraction with boiling point up to $3000 \mathrm{C}$, amount of added hydrogen donor $0.2 \mathrm{ml}$ to heavy oil and interelectrode distance $l p=8 \mathrm{~mm}$;

- test 10 - fraction with a boiling point up to $3000 \mathrm{C}$, the amount of added donor in an odor of $0.4 \mathrm{ml}$ to heavy oil and the interelectrode distance $l p=6 \mathrm{~mm}$;

- test 12 - fraction with boiling point up to $3000 \mathrm{C}$, amount of added hydrogen donor $0.5 \mathrm{ml}$ to heavy oil and interelectrode distance $l p=12 \mathrm{~mm}$;

- test 24 - fraction with boiling point up to $3000 \mathrm{C}$, amount of added hydrogen donor $0.2 \mathrm{ml}$ to heavy oil and interelectrode distance $l p=12 \mathrm{~mm}$.

The free energy of Gibbs was calculated from equation:

$$
\Delta G(T)=\Delta H(T)-T \Delta S(T) .
$$

The following graphs (1-3) show the heat capacity, enthalpy and Gibbs energy at various temperatures before and after treatment with an underwater spark discharge.

Figure 1 shows the heat capacity versus temperature.

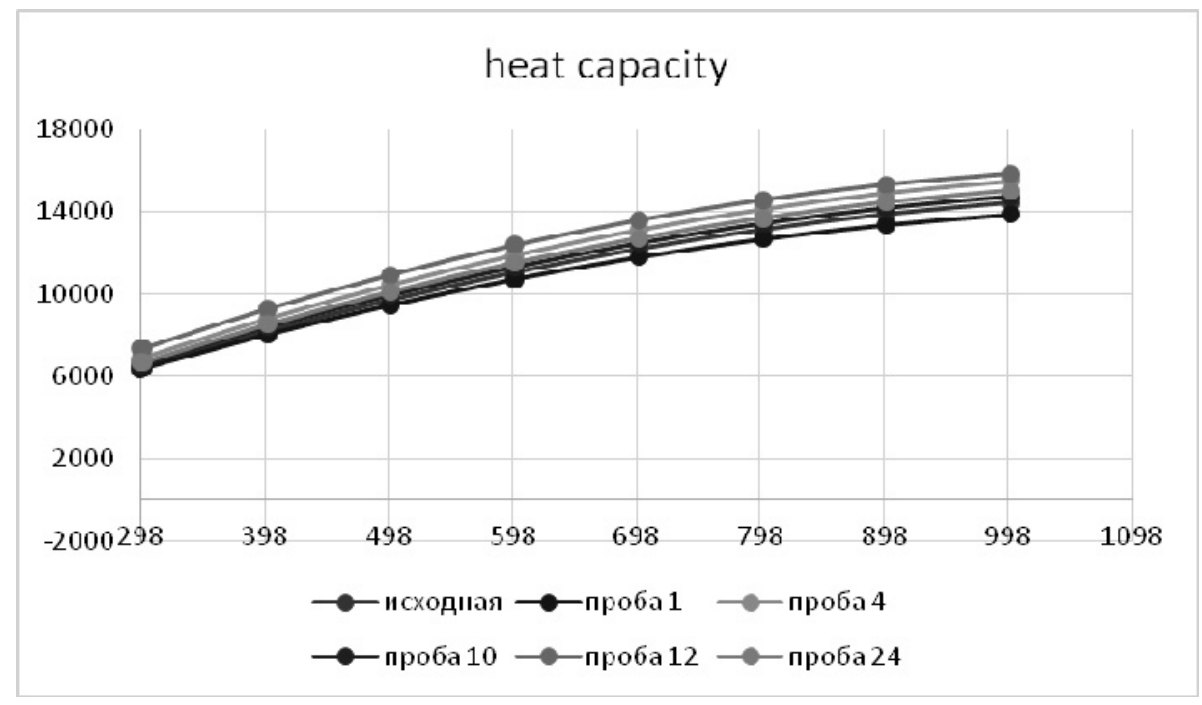

Figure 1. Heat capacity change of different samples heavy oil from temperature

Figure 2 shows the changes in enthalpy from temperature. 


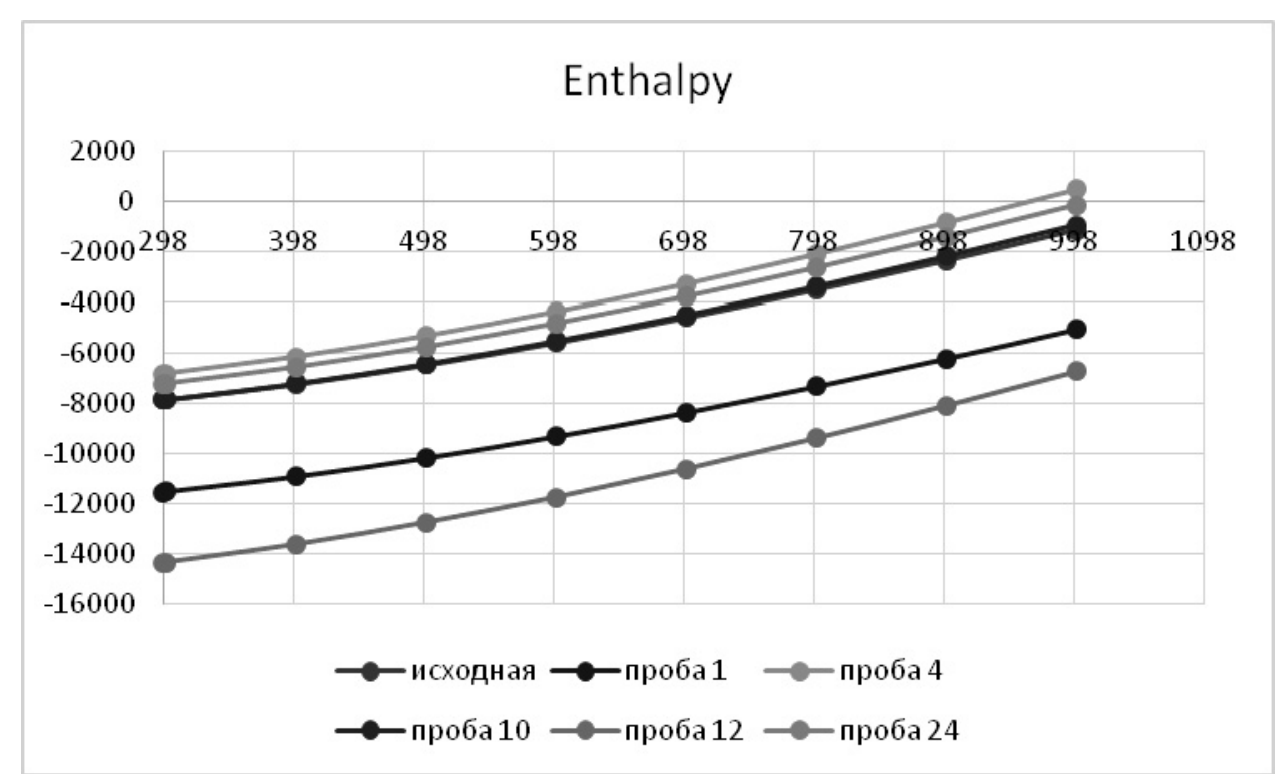

Figure 2. Change in the enthalpy of heavy oil from temperature

Figure 3 shows the dependence of Gibbs energy on temperature.

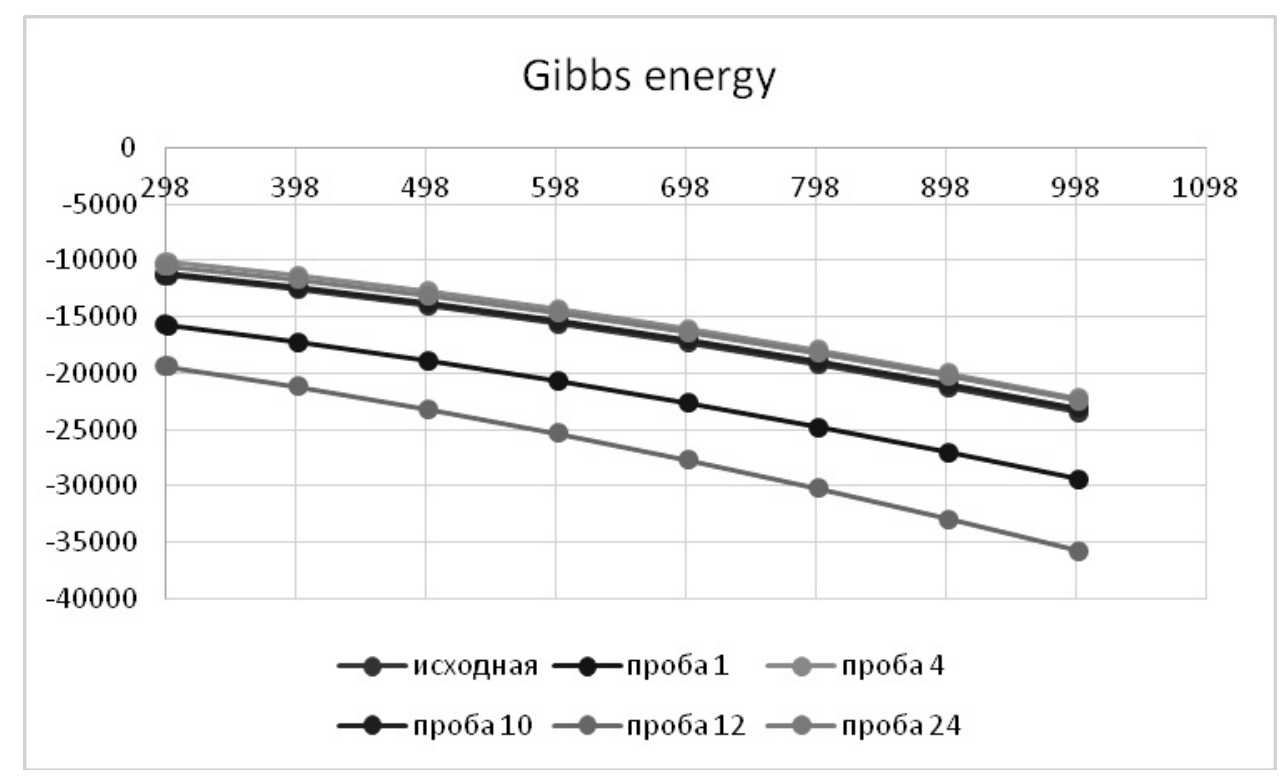

Figure 3. Temperature dependence of heavy oil's Gibbs energy

The thermodynamic function value of heavy oil's organic mass before and after treatment with an underwater spark discharge showed that with an increase in the the electrohydropulse (EHI) treatment duration from 2 to 10 minutes, an increase in the heat capacity Cp from $6396.579 \mathrm{~J} / \mathrm{mol} * \mathrm{~K}$ to $7309.395 \mathrm{~J} / \mathrm{mole} * \mathrm{~K}$. To study high-viscosity oil and hydrogenate with an underwater spark discharge help, the heat capacity, entropy $\Delta H$, Gibbs energy $\Delta G$, are extreme, and the thermodynamic potential $\Delta \Phi * *$ increases in the temperature range $298-1000 \mathrm{~K}$. The value of entropy in a given temperature range allows us to draw a conclusion about the significant EHI effect of treatment in the increasing the yield direction of the light and middle fraction.

The thermodynamic functions calculated by the additive method allow us to conclude that the duration of the EHI effect should not exceed 6 to 8 minutes. Increasing the treatment temperature with the EHI heavyoil effects help leads to the intermolecular interaction weakening. When the enthalpy of heavy oil changes and when the viscosity of the oil decreases, the yield fractions increases to $3000{ }^{\circ} \mathrm{C}$. The value of the enthalpy is composed the phase transitions heat of the heat capacity. The calculated values of the temperature dependence of the Gibbs free energy $\Delta \mathrm{G}$ for the activation heavy oil by electrohydropulse discharge are given 
in Tables 1 to 3. It follows from the data that in all considered cases thermodynamic stability is observed in the value of $\Delta G$ at a temperature $300 \mathrm{~T} 1000 \mathrm{~K}$.

It is known from literature sources that it is possible to remove heteroatoms without hydrogenation of aromatic rings [4]. The values of $\Delta G$ in this case do not depend on the number of functional groups character and the reaction of heteroatoms proceeds removal at a temperature $T<500 \mathrm{~K}$, and an increase in temperature leads to a series $\mathrm{OH}>\mathrm{NH}_{2}>\mathrm{SH}$.

Thus, on the basis of the additive method proposed by Professor Gyulmaliev, we calculated the thermodynamic functions of the organic mass of heavy oil and hydrogenates depending on the temperature and the duration of the exposure time with the help of EHE.

\title{
References
}

1 Романцова И.И. Термодинамика передачи водорода в модельных полицикленических системах / И.И. Романцова // Химия твердого топлива. - 1983. - № 1. - С. 103.

2 Гагарин С.Г. Термодинамика передачи водорода в полиядерных системах. Ароматические соединения с мостиковыми связями / С.Г. Гагарин, А.М. Гюльмалиев, А.А. Кричко // Химия твердого топлива. — 1990. — № 6. — С. 28-30.

3 Кусаиынов К. Влияние электрогидроимпульсной обработки на структуру тяжелых углеводородных соединении / К. Кусаиынов, Б.Р. Нусупбеков, А.Ж. Сатыбалдин // Хаос и структуры в нелинейных системах. Теория и эксперимент: материалы 6-й междунар. конф. ЕНУ. - Астана: Изд-во ЕНУ, 2008. - С. 267-270.

4 Калечиц И.В. Моделирование ожижения угля / И.В. Калечиц. - М.: РАН. Объединенный ин-т высоких температур, 1999. - $228 \mathrm{c}$.

\author{
А.Ж. Сатыбалдин, А.К. Муратова, И.А. Кыргызалина, \\ 3.К. Айтпаева, Б.Р. Нусупбеков, М.И. Байкенов
}

\section{Су асты разряд ұшқынының көмегімен өңделген ауыр мұнайдың органикалық массасының термодинамикалық функцияларын анықтау әдісі}

\begin{abstract}
Жоғары тұтқырлы және жоғары парафинді мұнайларға механикалық әсерімен байланысты мұнайларды құбыр желілерімен тасымалдуға дайындау әдістері қазіргі таңда мұнай айдау зауыттарының өзекті мәселесі болып табылады. Әдістердің ішіндегі ең дамығанына электргидроимпульстік разрядтар әдісін жатқызуға болатындығы белгілі, ол күрделі құрылым бөлшектерінің өлшемдері мен формасын өзгерту арқылы мұнай дисперсті жүйенің қасиеттерін реттеп отыруға мүмкіндік береді. Экологиялық таза синтетикалық сұйық отынды өндіруді жасау жоғары тұтқырлы мұнайды өңдеудің технологиялық үрдістерін жетілдіруді жобалайды. Мұндай міндетті шешу үшін тәжірибелі зерттеулерімен бірге жоғары тұтқырлы мұнайды өңдеудің әртүрлі жолдарының термодинамикалық талдау жұмыстары да қажет. Мұндай есептерді жоғары тұтқырлы көмірсу қосылыстарындағы әртүрлі кластағы қосылыстар үшін жүргізу керек. Қаражанбас кен орнының жоғары тұтқырлы мұнайының органикалық массасының өзгеріс механизмдерін тереңінен зерттеу жаңа жоғары тиімді гидрогенизация үрдістерін өңдеуде негізгі талап болып табылады. Аталмыш мақала Қаражанбас кен орнының жоғары тұтқырлы мұнайын өңдеудегі үрдістердің кинетикасы мен термодинамикасын зерттеуге арналған.
\end{abstract}

Кілm сөздер: электрогидроимпульстік разрядтар әдісі, дисперсті жүйе, технологиялық үрдістер, тұтқырлы мұнайдың органикалық массасы.

\author{
А.Ж. Сатыбалдин, А.К. Муратова, И.А. Кыргызалина, \\ 3.К. Айтпаева, Б.Р. Нусупбеков, М.И. Байкенов
}

\section{Метод определения термодинамических функций органической массы тяжелой нефти, обработанной с помощью подводного искрового разряда}

Способы подготовки нефтей к трубопроводному транспорту, связанные с механическим воздействием на высоковязкие и высокопарафинистые нефти, на сегодня являются актуальной проблемой нефтеперегонных заводов. Как известно, к наиболее перспективным из методов на сегодняшний день можно отнести метод электрогидроимпульсных разрядов, который позволяет регулировать свойства нефтяной дисперсной системы путем изменения размеров и форм сложных структурных единиц. Создание экологически чистого производства синтетического жидкого топлива предполагает совершенствова- 
ние технологии процесса облагораживания высоковязкой нефти. Для решения этой задачи наряду с экспериментальными исследованиями необходим термодинамический анализ различных путей ее облагораживания. Такие расчеты необходимо провести для различных классов соединений, содержащихся в высоковязких углеводородных соединениях. Глубокое изучение механизма превращений органической массы высоковязкой нефти месторождения Каражанбас является необходимым условием для разработки новых высокоэффективных процессов гидрогенизации. Статья посвящена изучению кинетики и термодинамики процессов переработки высоковязкой нефти месторождения Каражанбас.

Ключевые слова: электрогидравлический эффект, диэлектрическая проницаемость, температура, частота, сероводород, поляризуемость, термодинамический коэффициент, нефтепродукты, гетерогенная среда.

\section{References}

1 Romantsova, I.I. (1983). Termodinamika peredachi vodoroda v modelnykh politsiklenicheskikh sistemakh [Thermodynamics of hydrogen transfer in model polycyclenic systems]. Khimiia tverdoho topliva - Solid fuel chemistry, 1, 103 [in Russian].

2 Gagarin, S.G., Gyulmaliev, A.M., \& Krichko, A.A. (1990). Termodinamika peredachi vodoroda v poliiadernykh sistemakh. Aromaticheskie soedineniia s mostikovymi sviaziami [Thermodynamics of hydrogen transfer in polynuclear systems. Aromatic connections with bridged bonds]. Khimiia tverdoho topliva - Solid fuel chemistry, 6, 28-30 [in Russian].

3 Kussaiynov, K., Nussupbekov, B.R., \& Satybaldin, A.Zh. (2008). Vliianie elektrohidroimpulsnoi obrabotki na strukturu tiazhelykh uhlevodorodnykh soedinenii [Influence of electrohydropulse treatment on the structure of heavy hydrocarbon compounds]. Proceedings from Chaos and Structures in Nonlinear Systems. Theory and experiment: 6 mezhdunarodnaia konferentsiia ENU - 6th International Conference of ENU. (pp. 267-270). Astana: Izdatelstvo ENU [in Russian].

4 Kalechits, I.V. (1999). Modelirovanie ozhizheniia uhlia [Modeling of coal liquefaction]. Moscow: RAN Obedinennyi institute vysokikh temperatur [in Russian]. 